\title{
MORALITAS DALAM NOVEL 728 HARI IBU JEMBATANMU MENUJU SURGA KARYA DJONO W.OESMAN
}

\author{
Eka Ayu Permata Sari ${ }^{1}$, Ida Bagus Jelantik ${ }^{2}$, dan I Ketut Nama ${ }^{3}$ \\ 1,2,3) Universitas Udayana \\ Posel: ekaayups23@gmail.com \\ Artikel dikirim: 26 Agustus 2021; Diterima: 1 Oktober 2021
}

\section{MORALITY IN THE NOVEL 728 MOTHER'S DAY YOUR BRIDGE TO HEAVEN BY DJONO W.OESMAN}

\begin{abstract}
Novel 728 Hari Ibu Jembatanmu Menuju Surga by Djono W.Oesman was chosen as research data for several reasons. First, because this novel is a best seller. Second, this novel tells the true story of a person. Third, this novel has many useful references to morality. The analysis of this resersch uses structural theory and moral value theory as formulated by Burhan Nurgiyantoro's. Structural theory discusses the object of research in the intrinsic elements that build and literary work, among others, characterization, plot, and setting. Moral value theory is uused analyze the morality contained in the novel. The method used in this research is the library research method with reading, listening, and note taking techniques. Then, the data were analyzed using the analytical descriptive method. The results of this study consist of two parts. First, the structure of the novel 728 Hari:IJMS, the characters in the novel are the main character, Eva Meliana Santi, and additional characters, namely Sugiarti, Badarudin, Ryantori Ahmad, and Winantyo Adi Tamtomo (Nanan). The flow used consisnts of three stages, namely the initial stages, the middle stages, and the final stages. The setting of this novel is divided into three, namely place setting, time setting, and social setting. Second, the morality contained in the novel 728 Hari:IJMS and the moral of the main character in dealing with life's problems.
\end{abstract}

Kata Kunci: novel, sructural, morality

\section{PENDAHULUAN}

Karya sastra merupakan media untuk mengungkapkan pikiran pengarang. Karya sastra bersifat imajinatif, estetik dan menyenangkan pembaca (Irawanti, 2020). Karya sastra mengandung nilai-nilai yang bermanfaat bagi setiap pembacanya. Karya sastra yang diciptakan oleh pengarang mengandung nilai tertentu yang akan disampaikan kepada pembaca, misalnya nilai moral. Pembaca diharapkan dapat menemukan dan menelaah nilai moral tersebut (Murti, 2017). Novel sebagai salah satu karya sastra yang mengandung nilai-nilai sebagai gambaran realitas kehidupan yang digambarkan oleh pengarang berdasarkan pengalaman dan ungkapan perasaan pribadi pengarang (Rahmawati, 2019). 
Nilai-nilai moral adalah ajaran baik buruk perbuatan atau kelakuan, akhlak, kewajiban, budi pekerti dan Susila yang digunakan untuk menentukan batas-batas dari sifat, perangai, kehendak atau perbuatan secara layak dapat dikatakan benar, salah, baik, buruk (Elfanni, 2020). Berkaitan dengan moral, karya sastra khususnya novel dan kehidupan masyarakat merupakan dua hal yang tidak dapat dipisahkan. Moral yang disampaikan kepada pembaca melalui karya fiksi tentunya sangat berguna dan bermanfaat (Setyawati, 2013). Novel sebagai salah satu jenis karya sastra menampilkan sebuah dunia yang mengemas model kehidupan yang diidealkan (Akbar, 2012).

Terdapat banyak novel yang mengandung nilai moral, salah satunya adalah novel 728 Hari:IJMS karya Djono W.Oesman. Novel 728 Hari:IJMS karya Djono W.Oesman terbit pada tahun 2015, terdiri atas 336 halaman, diterbitkan oleh penerbit melvana. Novel 728 Hari:IJMS merupakan novel pertama, karena novel ini tentang kisah nyata seseorang. Novel ini termasuk novel yang best seller mencapai dua kali percetakan berturut-turut pada tahun 2015. Penulisnya, Djoko W.Oesman mengawali karier menjadi seorang wartawan Jawa Pos, 1 Agustus 1984 di Surabaya. Jabatan terakhir Redaktur pelaksana Indo Pos (anak Jawa pos di Jakarta). Dia pernah dinobatkan menjadi penulis features terbaik di Jawa Pos.

Berdasarkan latar belakang di atas, analisis novel 728 Hari:IJMS karena beberapa alasan. Pertama. Novel 728 Hari:IJMS menggambarkan kisah nyata seorang wanita yang mengidap penyakit lupus. Kedua, sepengetahuan penulis belum ada yang menganalisis novel 728 Hari:IJMS di Fakultas Ilmu Budaya Universitas Udayana. Maka dari itu, penulis tertarik meneliti novel 728 Hari:IJMS karya Djono W.Oesman ini dari segi moralitas menngunakan tinjauan sosiologi sastra. Sosiologi maupun sastra memiliki objek kajian yang sama, yaitu manusia dalam masyarakat memahami hubungan antarmanusia dan proses yang timbul dari hubungan tersebut (ipritania, 2015).

Kajian pustaka dalam penelitian terdapat empat penelitian yang sejenis dengan penelitian ini, yaitu sebagai berikut.

Penelitian oleh Sandra Fransiska (2004), berjudul “Aspek Moral dalam Lirik Lagu Jamrud dengan Kajian Sosiologi Sastra". Hasil penelitian ini memaparkan aspek yang berkaitan dengan realitas kehidupan masa kini, aspek moral yang yang ditemukan dalam penelitian ini meliputi moral kemanusiaan, tingkah laku, dan pergaulan. Penelitian Setiyawan Eko (2012) berjudul "Aspek Moral dalam Novel Doa Ibu Sekar Ayu Asmara: Tinjauan Sosiologi Sastra". Hasil penelitian ini mendeskripsikan struktur yang terdapat dalam novel dan mendeskripsikan aspek 
moral yang terkandung. Struktur dalam novel Doa Ibu terdiri dari tema, alur, penokohan dan latar.

Skripsi Anggun Khitriana Lestari (2012) yang berjudul "Aspek Moralitas dalam Novel Edensor karya Andrea Hirata:Kajian Sosiologi Sastra". Pada penelitian ini sang pengarang menceritakan kisah dalam novel Edensor berdasarkan pada kehidupan di masyarakat. Aspek moral yang disampaikan sangat beragam yaitu tentang keseharian tokoh utama yang sangat menginspirasi. Skripsi Sri Sulastri (2008) yang berjudul "Aspek Moral dalam Kumpulan cerpen In Memoriam X karya A.R. Loebis: Kajian Sosiologi Sastra". Pada penelitian ini ditunjukkan bahwa aspek moral pada kumpulan cerpen In Memoriam X karya A.R. Loebis yang dianalisis adalah pencurian sebagai perbuatan yang melanggar hukum, dan persahabatan yang ternodai oleh penipuan.

Teori yang digunakan dalam menganalisis adalah teori struktural dan teori sosiologi sastra. Teori struktural dilakukan untuk mengidentifikasi, mengkaji, dan mendeskripsi fungsi dan hubungan unsur apa saja yang ada dalam sebuah karya sastra (Susanti, 2013). Penelitian ini menggunakan teori struktural yang dirumuskan oleh Nurgiyantoro memfokuskan unsur-unsur yang membangun karya sastra, yaitu latar, alur dan penokohan. Menurut teeuw (1984:154), analisis struktural adalah salah satu langkah dan sarana atau alat dalam proses pemberian makna dan dalam usaha ilmiah untuk memahami proses itu dengan sempurna. sosiologi sastra adalah menghubungkan pengalaman tokoh-tokoh khayalik dan situasi ciptaan pengarang itu dengan keadaan sejarah yang merupakan asal-usulnya (Damono, 1978:8-9). Secara definisi sosiologi sastra adalah analisis, pembicaraan terhadap karya sastra dengan mempertimbangkan aspek-aspek kemasyarakatan (tamaraw, 2015).

Penelitian ini merupakan penelitian kualitatif yang menggunakan metode studi pustaka. Metode yang digunakan dalam penelitian ini adalah metode deskriptif, yaitu penelitian yang dilakukan atas dasar fakta untuk mengetahui moralitas yang terkandung dalam novel (Septiningsih, 2017). Sumber data dalam penelitian ini adalah novel 728 Hari:IJMS karya Djono W.Oesman. metode yang digunakan dalam pengumpulan data adalah studi pustaka. Teknik yang digunakan berupa baca, simak, dan catat. Data utama dalam penelitian ini adalah novel 728 Hari:IJMS dengan cara membacanya secara intensif dan berulang-ulang, kemudian mencatat data yang penting, dan selanjutnya data akan dianalisis mengunakan metode deskriptif analitik. Metode deskriptif ini menguraikan serta memberikan pemahaman dan penjelasan mengenai data yang ada. Teknik analisis data ini menggunakan Teknik baca, simak, dan catat. 
Hasil analisis penelitian ini disajikan menggunakan metode deskriptif. Teknik yang digunakan dalam menyajikan hasil analisis data adalah dengan format penulisan skripsi yang telah ditentukan, yaitu. Bab I Pendahuluan, Bab II Analisis Struktural novel 728 Hari:IJMS, Bab III Moralitas yang terkandung dalam novel dan Moral tokoh utama dalam menghadapi persoalan hidup, Bab IV Penutup yang berisi simpulan dan saran.

\section{HASIL DAN PEMBAHASAN}

\section{Analisis Struktur}

Analisis struktur bertujuan untuk menjelaskan unsur intrinsik karya sastra dalam novel 728 Hari:IJMS karya Djono W.Oesman. Unsur intrinsik karya sastra meliputi, tema, penokohan, alur, latar, sudut pandang, gaya Bahasa, dan amanat. Menurut Stanton (dalam Sugihastuti \& Rossi (2019:22)) karakter, alur, dan latar merupakan fakta-fakta cerita. Elemen-elemen ini berfungsi sebagai catatan kejadian imajinatif dari sebuah cerita.

\section{Penokohan}

Penokohan atau perwatakan merupakan salah satu unsur terpenting dalam sebuah fiksi (Yulianti, 2018). Tokoh utama dalam novel 728 Hari:IJMS adalah Eva meliana Santi, seorang wanita cantik dan ceria yang mengidap penyakit lupus. Adapun tokoh tambahan yaitu, Sugiarti merupakan ibu Eva, Badarudin ayah Eva, Ryantori Ahmad merupakan cinta pertama Eva, dan winantyo Adi Tamtomo merupakan suami Eva.

Alur

Alur sebuah cerita haruslah padu. Antara peristiwa yang satu dengan yang lain, ada hubungan, ada sifat saling keterkaitan. Untuk memperoleh keutuhan suatu alur cerita, Aristoteles (dalam Nurgiyantoro, 2009:142), mengemukakan bahwa sebuah alur haruslah terdiri atas tahap awal (beginning), tahap tengah (middle), dan tahap akhir (end).

Tahapan alur dalam novel 728 Hari:IJMS diuraikan pada tahapan-tahapan berikut. Tahap awal diawali dengan perkenalan Eva adalah seorang gadis cantik dan ceria. Dia lahir di Desa, ibunya sebagai ibu rumah tangga, dan ayahnya bekerja sebagai PNS Penprov DKI. Awal sebelum Eva dinyatakan mengidap lupus, dia jatuh pingsan di sekolahannya. Sejak saat itu dia sering pingsan jika terkena sinar matahari atau jika sedang kelelahan. 
Tahap tengah muncul konflik saat tokoh Eva harus menjalani operasi pengambilan cairan sumsum tulang belakang. Selesai dengan operasi sumsum tuang belakang dia juga harus menjalani operasi pembungan limpah karena limpah pada tubuhnya sudah membengkak, tetapi keluarga tidak menyetujui cara dokter dengan membuang limpahnya, akhirnya keluarga Eva memilih memakai jalur obatobatan. Lupus yang di deritanya semakin parah saat tokoh Eva mengalami perubahan pada fisiknya wajah yang membengkak, dan berat badan naik.

Tahap akhir, bagian ini sebagai tahap peleraian, menampilkan adegan klimaks. Akhir ceriya ditunjukkan saat tokoh Eva menikah dengan lelaki yang mencintai dirinya. Nanan menikahi Eva pada tahun 2004, tetapi pernikahan mereka tidak luput dengan datangnya cobaan. Pada tahun 2008 Eva dinyatakan hamil, tetapi kehamilannya memiliki resiko yang sangat besar. Hasilnya pada bulan agustus Eva mengalami keguguran keluarga sangat sedih. Kehidupan Nanan dan Eva berjalan seperti biasanya meskipun Eva mengangap penikahan ini terasa hambar, tetapi Eva senang karena Nanan memperbolehkan dia bekerja asal tidak sampai kelelahan. Akhirnya pada tanggal 1 Apri 2014 Eva menghembuskan napas terakhirnya, semua yang tinggalkan merasa sedih, tetapi mereka merelakannya karena Eva sudah tidak merasakan sakit lagi.

\section{Latar}

Unsur latar dibedakan menjadi tiga, yaitu latar tempat, latar waktu, dan latar sosial. Latar tempat yang terdapat pada novel 728 Hari:IJMS adalah SDN 3 Pondok Bambu, RSI (Rumah Sakit Islam), RSCM (Rumah Sakit Cipto Mangunkusumo), Rumah Sakit Kramat, Kantor YLI (Yayasan Lupus Indonesia), dan Kantor Dahlan.

Latar waktu dalam novel 728 Hari:IJMS di sampaikan dengan menggunakan waktu tahun, beberapa tahun yang tercantum sebagai latar waktu adalah dari tahun 1986-2014.

Latar sosial yang tergambar pada novel 728 Hari:IJMS adalah keluarga Eva yang ada di desa. Kakek dan Nenek Eva termasuk orang yang mampu di Dusun Duduhan. Dusun tersebut adalah dusun kecil yang penduduknya hanya memiliki sekitar lima puluh keluarga, Latar sosial mengenai pandangan, cara berpikir, dan bersikap dalam aturan norma masyarakat, dan latar sosial yang atas melukiskan adat istiadat yang ada di daerah Eva. Selametan adalah tradisi yang dilakukan oleh masyarakat jawa. Selametan adalah suatu bentuk acara syukuran dengan mengundang beberapa kerabat atau tetangga. Acara syukuran biasanya dilakukan 
dengan cara doa bersama dan makan-makan. Hidangan yang disediakan biasanya berupa nasi tumpeng dan jajan-jajanan pasar.

\section{Analisis Moralitas dan Moral Tokoh dalam Menghadapi Persoalan Hidup}

Moral merupakan salah satu nilai yang digunakan dalam kehidupan seharihari (Ambarwati, 2017). Nilai moral yang terkandung dalam novel 728 Hari:IJMS dapat dikategorikan sifat dan perilaku manusia yang melekat dalam menjalani hidup, yaitu moral dalam hubungan manusia dengan diri sendiri, hubungan manusia dengan Tuhan, dan hubungan manusia dengan manusia lain. Moral adalah tolak ukur masyarakat dalam menjalani kehidupan. Kehidupan bermasyarakat selalu diwarnai dengan banyaknya masalah yang melanggar sebuah norma yang berlaku (Nirmala, 2021).

Moral hubungan manusia dengan diri sendiri yang terdapat dalam novel ada dua bentuk varian, yaitu keikhlasan dan percaya diri (PD). Moral hubungan manusia dengan Tuhan terdapat dua bentuk varian, yaitu sholat dan berdoa kepada Tuhan. Moral hubungan manusia dengan manusia lain terdapat dua bentuk varian, yaitu nasihat orang tua kepada anak dan kasih sayang orang tua kepada anak.

Moral tokoh utama dalam menghadapi persoalan, moral merupakan sesuatu yang ingin disampaikan oleh pengarang kepada pembaca merupakan makna yang terkandung dalam sebuah karya sastra dan makna yang disarankan lewat cerita (Nurgiyantoro, 2009:321). Moral tokoh merupakan nilai baik buruk yang dilakukan oleh tokoh dalam karya sastra itu sendiri. Moral tokoh yang terdapat dalam novel 728 Hari:IJMS terdapat 2 varian yaitu suka bekerja keras, tidak tabah menghadapi cobaan.

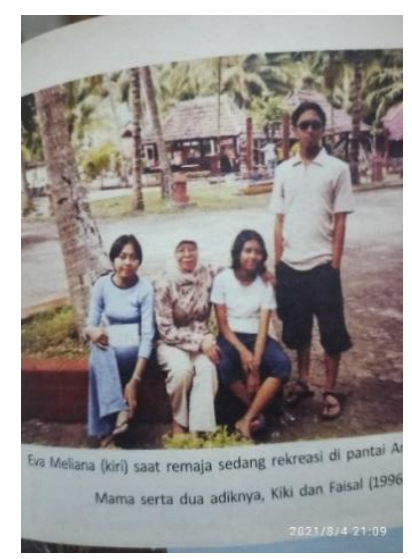

Foto 1. Eva Meliana (kiri) saat rekreasi di pantai ancol bersama mama serta dua adiknya. (foto: novel 728 Hari:IJMS, tahun 1996). 


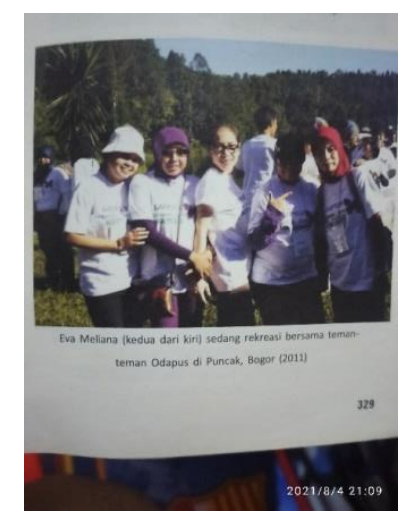

Foto 2: Eva Meliana (kedua dari kiri) saat rekreasi bersama teman-teman odapus.

(Foto: novel 728 Hari:IJMS, Bogor 2011).

\section{SIMPULAN}

Berdasarkan hasil pembahasan di atas, simpuan artikel ini diuraikan sebagai berikut. Pertama, berdasarkan analisis sktuktur novel 728 Hari:IJMS karya Djono W.Oesman unsur intrinsik yang dibahas adalah penokohan, alur dan latar. Penokohan dalam novel 728 Hari:IJMS terdapat tokoh utama yaitu Eva Meliana Santi dan tokoh tambahan yaitu Sugiarti, Badarudin, Ryantori Ahmad, dan Winantyo Adi Tamtomo (Nanan). Alur novel 728 Hari:IJMS dibagi menjadi tiga yaitu, tahap awal, tahap tengah, dan tahap akhir. Latar dalam novel 728 Hari:IJMS dibagi menjadi tiga yaitu latar tempat, latar waktu, dan latar sosial.

Kedua, analisis moralitas dan moral tokoh yang terdapat dalam novel 728 Hari:IJMS. Moralitas dibagi menjadi empat, yaitu moral dalam hubungan manusia dengan diri sendiri terdapat dua bentuk varian: keikhlasan dan percaya diri (PD), moral dalam hubungan manusia dengan Tuhan terdapat dua bentuk varian: sholat dan berdoa kepada Tuhan, moral dalam hubungan manusia dengan manusia lain terdapat dua bentuk varian: nasihat orang tua kepada anak dan kasih sayang orang tua kepada anak, dan yang terakhir moral tokoh utama dalam menghadapi persoalan terdapat dua varian yaitu bekerja keras dan tidak tabah dalam menghadapi ujian. Moralitas yang terdapat dalam novel ini pengarang ingin menunjukkan agar bermanfaat bagi pembaca

\section{UCAPAN TERIMA KASIH}

Puji dan syukur penulis panjatkan kepada Tuhan yang Maha Esa karena atas rahmat dan karunia-Nya, penulis dapat menyelesaikan jurnal ini dengan baik. 
Terima kasih kepada Dr. Drs. Ida Bagus Jelantik S.P., M.Hum selaku pembimbing satu dan Drs. I Ketut Nama, M.Hum. selaku pembimbing dua yang senantiasa sabar memberikan bimbingan dalam proses penyelesaian skripsi. Ucapan terima kasih juga penulis sampaikan kepada seluruh Dosen Program Studi Satra Indonesia, Fakultas Ilmu Budaya, Universitas Udayana atas segala ilmu dan pengetahuan yang telah diberikan. Terima kasih kepada keluarga tercinta, Bapak Kasaji dan Ibu Nur Halimah selaku orang tua yang selalu memberikan doa, semangat, kasih sayang, dan perhatian yang terhingga kepada penulis hingga bisa menyelesaikan penelitian ini. Terima kasih kepada adik penulis, Riski Amanda Mukaromah yang selalu memberikan semangat agar bisa menyelesaikan penelitian ini.

\section{DAFTAR PUSTAKA}

Akbar, S. (2012). Kajian Sosiologi Sastra dan Nilai Pendidikan dalam Novel Tuan Guru Karya Salman Faris (Doctoral dissertation, UNS (Sebelas Maret University)).

Ambarwati, R. 2017. Aspek Moralitas Dalam Novel Anak-Anak Pangaro Karya Nun Urtono El Banbary Kajian Sosiologi Sastra dan Implementasinya Sebagai Bahan Ajar Sastra Indonesia di SMP. Skripsi. Surakarta: Universitas Muhammadiyah Surakarta.

Damono, Sapardi Djoko. 1978. Sosiologi Sastra Sebagai Pengantar Ringkas. Jakarta: Pusat Pengembangan dan pembinaan Bahasa.

Elfanni, T. Z. 2020. Nilai Moral dalam Novel Orang-Orang Biasa Karya Andrea Hirata. Jurnal. Lateralisasi, (2)8.

Fransiska, Sandra. 2004. Aspek Moral dalam Lirik Lagu Jamrud yang berjudul Putri Kajian Sosiologi Sastra. Skripsi. Surakarta: Universitas Muhammadiyah.

Irawanti A. A., \& Agustiani, T. 2020) Analisis Nilai Moral Dalam Novel Surat Kecil Untuk Tuhan Agnes Davonar. Jurnal. Sukabumi: Universitas Muhammadiyah Sukabumi.

Ipritania, E. (2015). “Konflik Sosial Dalam Novel Cintrong Paju-Pat Karya Suparto Brata, Tinjauan Sosiologi Sastra" ADITYA-Pendidikan Bahasa dan Sastra Jawa, 6(4). Lestari, Anggun Khitriana. 2012. Aspek Moralitas dalam Novel Endensor Kajian Sosiologi Sastra. Skripsi. Semarang: Universitas Diponegoro.

Murti, S., \& Maryam, S. 2017. Analisis Nilai Moral Novel Bulan Jingga Dalam Kepala Karya M. Fadjroel Rachman: Kajian Bahasa, Sastra, dan Pengajaran. Jurnal. STKIPPGRI Lubuklinggau.

Nirmala, D. R. 2021. Analisis Moralitas Tokoh Pada Novel "uhan, Izinkan Aku Menjadi Pelacur! Karya Muhidin M. Dahlan Sebuah Kajian Dekontruksi. Jurnal. Mataram: Universitas Muhammadiya Mataram.

Nurgiyantoro, Burhan. 2009. Teori Pengkajian Fiksi, Yogyakarta: Gadjah Mada University Pres. 
Rahmawati, E., \& Achsani, F. “Nilai-Nilai Moral Novel Peter Karya Risa Saraswti dan Relevansinya dengan Pembelajaran Bahasa Indonesia“. Lingua Franca: Jurnal Bahasa, Sastra, dan Pengajarannya. (1)3.

Robert Stanton. 2012. Teori Fiksi Robert Stanton. (Sugiharti dan Rossi). Yogyakarta: Pustaka Pelajar.

Setyawati, E. 2013. "Analisis Nilai Moral Dalam Novel Surat Kecil Untuk Tuhan

Karya Agnes Davonar (Pendekatan Pragmatik)". Skripsi. Yogyakarta: Universitas Negri Yogyakarta.

Setiyawan, Eko. 2012. Aspek Moral dalam Novel Doa Ibu Karya Sekar Ayu Asmara:

Tinjauan Sosiologi Sastra. Skripsi. Surakarta: Universitas Muhammadiyah.

Septiningsih, L. 2017. "Moralitas Dalam Novel Para Priyayi Karya Umar Kayam". Jurnal. Pujangga, (1)3.

Sulastri, Sri. 2008. Aspek Moral dalam Kumpulan Cerpen In Memoriam X Karya A.R Loebis Kajian Sosiologi Sastra. (Skrips)i. Surakarta: Universitas Muhammadiyah.

Susanti, K. D. 2013. Analisis Struktural dan Kajian Religiusitas Tokoh Dalam Novel Rumah Tanpa Jendela Karya Asma Nadia. kripsi. Semarang: Universitas Diponegoro.

Tamaraw, Juna. 2015. Analisis Sosiologi Sastra Tehadap Novel $5 \mathrm{~cm}$ Karya Donny Dhirgantoro. Jurnal. Manado: Universitas Sam Ratulangi.

Teeuw, A. 1984. Sastra dan Ilmu Sastra: Pengantar Teori Sastra. Yogyakarta: PT Gramedia.

Yuliati, Eva. 2018. Kepercayaan Tradisional Masyarakat Jawa dalam Novel Suti Karya Sapardi Djoko Damono: Kajian Sosiologi Sastra. Jurnal. Universitas Udayana.

\section{PROFIL PENULIS}

Eka Ayu Permata Sari adalah mahasiswi Prodi Sastra Indonesia angkatan tahun 2016. Sebelum menjadi mahasiswi Eka menempuh ilmu di pesantren selama 6 tahun. Eka diterima sebagai mahasiswi Prodi Sastra Indonesia melalui jalur undangan. Pada tahun 2017 Eka pernah menjadi pendamping kelompok (PK) dalam rangka Student Day Fakultas Ilmu Budaya. Pada tahun 2018 pernah menjadi koordinator p32k dalam rangka pekan sastra jurusan Sastra Indonesia.

Dr. Ida Bagus Jelantik S. Pidada, M.Hum. lahir di Karangasem Bali. Menyelesaikan Studi di Unud dan UGM. Sejak tahun 1989 sebagai Staf Prodi Sastra Indonesia FIB Unud. Pernah meneliti untuk LPPM Unud, The Toyota Foundation, Pemkab Karangasem, dan Pemkot Denpasar. Kadangkala menulis untuk Bali Post dan Majalah WARTAM. Juga sebagai Redpel WARTAM, Ketua Badan Penerbit PHDI, Anggota Basada PHDI, Wakil Ketua YPWK UNHI, Anggota HISKI, 
Kelompok Ahli Pembangunan, Dewan Pendidikan, dan Dewan Kota Pusaka Denpasar, serta Ketua Yayasan Bali Shanti.

Drs. I Ketut Nama, M. Hum. menyelesaikan studi sarjana (S1) di Prodi Sastra Indonesia Fakutas Sastra Unud tahun 1988. Sejak 1 Maret 1989 diangkat sebagai tenaga edukatif di almamaternya. Mulai September 1998 kuliah di Program Pascasarjana (S2 Linguistik, konsentrasi Wacana Sastra), selesai Agustus 2001. Pernah menjadi Sekretaris Jurusan (2009-2011) dan Ketua Jurusan (2011-2013) Sastra Indonesia, Fakultas Sastra (kini Fakultas Ilmu Budaya) Unud. Selain mengampu beberapa mata kuliah di bidang sastra, juga aktif melakukan penelitian dan mengikuti berbagai pertemuan ilmiah. 